UDC $621.313 .04: 621.319 .4: 621.318 .4: 621.565 .92$

\title{
ボビンコイル形高効率コンデンサモータの 開発
}

$\begin{array}{lllllll}\text { 正員 } & \text { 横 } & \text { 塚 } & & \text { 勉 } & \text { (群 } & \text { 馬 } \\ \text { 正員 } & \text { 馬 } & \text { 場 } & \text { 英 } & \text { 治 } & \text { (群 } \text { 馬 } 大) \\ \text { 非会員 } & \text { 小 } & \text { 林 } & \text { 俊 } & \text { 夫 } & \text { (日本サーボ }\end{array}$

\section{1. まえがき}

棆蔵庫用のファン駆動用電動機として出力が $1 \mathrm{~W}$ 程度の電動機が数多く使用されているが，この種の電 動機では効率を高め，構造を簡単にして低価格とする ことが強く要求されている。石油危機以前は効率はあ まり問題とされず, 入力が $8 \mathrm{~W}$ 程度のくま取り電動 機が広く使用されていた。その後の省エネルギーの強 い要求により，極の形状，くま取りコイルの位置およ びその寸法などの最適化により入力を $6.5 \mathrm{~W}$ 程度で 低下させることができた。しかし，くま取り電動機で はこれが限界であった。そこでこれら二つの要求に沿 って構造が簡単なボビンコイル形コンデンサモータ (以後，ボビンコイルモータと呼ぶ）を開発し，入力 を 3.5 W まで低減できたので，そのときの問題につ

\section{き報告する。}

コンデンサモータの解析法についてはMorril1氏(1), 岐部氏(2)らの報告があり，これらは正逆に回転する二 つの回転磁界として解析するものであるが，最も基本 的解析法とみることができる。また, 平衡運転条件, トルク, 効率など主要な特性については見城氏ら (3) (5) の報告があり，これらによって通常の形のコンデンサ モータの解析法ならびに特性についてはほぼ明らかに なったとみられる。しかし，ボビンコイル形とするこ とによって発生する問題，すなわち，固定子歯の先端 を磁気的に短絡（以後，ブリッジと呼ぶ）することの 特性への影響，毎極每相溝数が 1 で，1/2 の短節巻と することの影響などについてはまだ明らかにされてい ない。これらはボビンコイルモータ固有の問題である

Development of a Bobbin-coil Type High Effciency Capacitor Motor. By Tsutomu Yokozuka, Member, Eiji Baba, Member (Faculty of Engineering, Gunma University) \& Toshio Kobayashi, Non-member (Japan Servo Co., Ltd).

棤塚 勉: 正員，群馬大学工学部電気工学科

思場英治: 正員, 群馬大学工学部電気工学科

小林俊夫：非会員，日本サーボ(株)

昭 $59-10$
が，効率およびトルク特性に大きな影響を与えるので 重要な問題である。

本文では既に一部報告したように(10)小形のボビン コイルモータの問題点を示し，その特性ならびに原因 を明らかにして，改善法について検討するすので

（1）プリッジが特性に及ぼす影響，特に効率への 影響を明らかにし，改善法を示す。

（2）ボビンコイルモータでは測定值から求めた等 価回路定数（以後, 定数之呼ぶ）を使ってトルクを計 算するとかなり大きな誤差を生ずるが，その原因を究 明する。また，空間高調波起磁力の影響を明らかにす る。

（3）小形のコンデンサモータでは巻線が細くなる ので断線事故を起こしやすく，信頼性に問題が出てく る。そこで補助巻線と並列にコンデンサを接続し，乙 れに主巻線を直列接続する方式について検討する。

ボビンコイルモータでは多くの場合, 固定子極の機 械的強度をむたせるためにブリッジを付けるが，（1） ではブリッジを付けた機種と付けない機種を試作して 特性を比較し，その影響を明らかにする。(2)はボビ ンコイルモータでは毎極毎相满数が 1 で, 1/2 の短節 巻となるために空間高調波起磁力の影響が特に大きい こと，測定值から求めた定数では二次抵抗および二次 漏れリアクタンスに大きな誤差がでることなどを示 す。(1), (2) ばヒビンコイルモータ固有の問題之み ることができるが，とれら関する報告はまだないよ うである。(3)の線径が細くなる問題は小形のコンデ ンサモータで一般的に起る問題で，ての結線方式にし たときの特性の計算法, 平衡運転条件などを明らかに する。この結線は既に使用されているが，解析法なら びに特性に関する報告はまだないようである。本文に 示す開発機種がほほ普通の結線方式の限界で，これよ り小形にする場合はこの結線にするのが良いと考え る。 


\section{2. 特性の計算法}

〈2.1〉基本波成分 普通の形のコンデンサモー 夕の特性仿対称座標法で解析でき，その磁界は正道に 回転する二つの回転磁界之考えることができる(1)(2)。 正方向任回転する成分（正相分）の主巻線相の等価回 路は図 1 (a)で表わすことができる。なお，本文で扱 う主な記号は次の諸量を示すすのとする。

$V_{1}:$ 電源電压 $(\mathrm{V}), f:$ 電源の周波数 $(\mathrm{Hz})$

$p:$ 極数, $s:$ すべり

$r_{1}:$ 主巻線相一次巻線抵抗 $(\Omega)$

$x_{1}, x_{2}$ : 主巻線相一次, 二次 (一次換算值) 漏れり

$$
\text { アクタンス }(\Omega)
$$

$x_{m}$ : 主巻線相励磁りアクタンス $(\Omega)$

$r 2:$ 主巻線相二次 (一次換算值) 抵抗 $(\Omega)$

$r_{i}:$ 主巻線相等価鉄損抵抗 $(\Omega)$

$W_{m}, W_{a}:$ 主巻線，補助巻線の巻数

$a:$ 巻数比 $\left(W_{\mathrm{a}} / W_{m}\right)$

$x_{\bullet}:$ コンデンサリアクタンス主巻線相換算值 $(\Omega)$

$\dot{Z}_{p}, \dot{Z}_{n}: x_{m}, r_{i}$ 含めた正相, 逆相分の回転子側の

$$
\text { インピーダンス }(\Omega)
$$

$\dot{I}_{p}, \dot{I}_{n}:$ 基本波成分の正相，逆相分電流 (A)

$\dot{I}_{m}, \dot{I}_{a}:$ 主巻線，補助巻線電流主巻線相換算値 $(\mathrm{A})$

$W_{p}, W_{n}:$ 正相分, 逆相分二次入力 $(\mathrm{W})$

$T:$ トルク $(\mathrm{N}-\mathrm{m}), T_{n}: n$ 次空間調波卜ルタ

$Y:$ 効率 $(\%), n:$ 空間高調波次数

$b_{n}: n$ 次空間調波起磁力の大きさ

$k_{m n}, k_{a n}$ : 主巻線, 補助巻線相の $n$ 次空間調波起磁力 の比（基本波成分基潐）

(a)

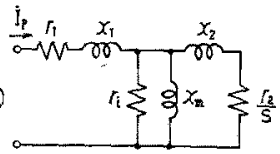

(b)

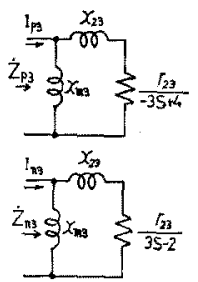

(C)

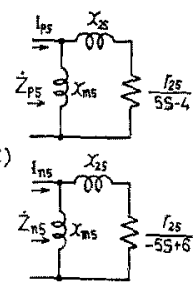

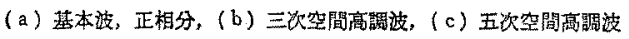
园 1 等 価回 路

Fig. 1. Equivalent circuits, (a) for fundamental, positive-sequence component, ( $b$ ) for third space harmonic component, (c) for 5-th space harmonic component.

\section{$Y_{m}:$ 最大効率 $(\%)$}

$r_{23}:$ 三次空間調波の二次抵抗 $(\Omega)$

両相の鉄心の形状が等しく，巻線軸角度が $\pi / 2$ で， 両相の銅量が等しい之すると(こ机らの条件牥多くの 場合成立)， $\dot{I}_{p}, \dot{I}_{n}$ はそれぞれ(5)

$$
\begin{aligned}
\dot{I}_{p}= & \left\{Z_{n r}+r_{1}+Z_{n j} / a+x_{1} / a+j\left(Z_{n j}\right.\right. \\
& \left.\left.+x_{1}-x_{c}-Z_{n r} / a-r_{1} / a\right)\right\} V_{1} / D \\
& \ldots \ldots \ldots \ldots \ldots \ldots \ldots \ldots \ldots \ldots \ldots \ldots \ldots \ldots \ldots \ldots \\
\dot{I}_{n}= & \left\{Z_{p r}+r_{1}-Z_{p j} / a-x_{1} / a+j\left(Z_{p j}\right.\right. \\
& \left.\left.+x_{1}-x_{c}+Z_{p r} / a+r_{1} / a\right)\right\} V_{1} / D
\end{aligned}
$$

但し,

$$
\begin{aligned}
D= & \left\{2\left(Z_{p r}+r_{1}\right)\left(Z_{n r}+r_{1}\right)\right. \\
& -\left(Z_{p j}+x_{1}-x_{c}\right)\left(Z_{n j}+x_{1}\right) \\
& \left.-\left(Z_{n j}+x_{1}-x_{c}\right)\left(Z_{p j}+x_{1}\right)\right\} \\
& +j\left\{\left(Z_{p r}+r_{1}\right)\left(2 Z_{n j}+2 x_{1}-x_{c}\right)\right. \\
& \left.+\left(Z_{n r}+r_{1}\right)\left(2 Z_{p j}+2 x_{1}-x_{c}\right)\right\} \\
\dot{Z}_{p}= & \frac{1}{\frac{1}{r_{i}}+\frac{1}{j x_{m}}+\frac{1}{\left(r_{2} / s\right)+j x_{2}}} \equiv Z_{p r}+j Z_{p j}
\end{aligned}
$$

$$
\dot{Z}_{n}=\frac{1}{\frac{1}{r_{i}}+\frac{1}{j x_{m}}+\frac{1}{r_{2} /(2-s)+j x_{2}}}
$$$$
\equiv Z_{n r}+j Z_{n j}
$$

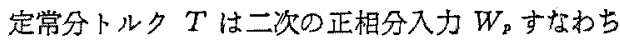
$r_{2} / s$ の電力之二次逆相分入力 $W_{n}$ の差加ら(5)式で 求まる。乙の場合，等価鉄損抵抗 $r$ の電力住固定子 内で熱になるだけでトルクには直接関係ない上考えら れる。入力 $W_{i}$ は $\dot{I}_{m}, \dot{I}_{a}$ の電源電生化対する位相差 をえれぞれ $\varphi_{m} ， \varphi_{\alpha}$ とするよ(6)式で求まり，出力は (7)式，効率 $Y$ は(8)式で求めるととができる(5)。

$$
\begin{array}{r}
T=\frac{2}{4 \pi f / p}\left(W_{p}-W_{n}\right)(\mathrm{N}-\mathrm{m}) \ldots \ldots \ldots \\
W_{i}=V_{1} I_{m} \cos \varphi_{m}+V_{1} I_{a} \cos \varphi_{a}(\mathrm{~W}) \\
\ldots \ldots \ldots \ldots \ldots \ldots \ldots \ldots \ldots \ldots \ldots \ldots \ldots \ldots \ldots \ldots \ldots \ldots \ldots \ldots \\
W_{0}=2\left(W_{p}-W_{n}\right)(1-s)(\mathrm{W}) \ldots \ldots \ldots \ldots \\
Y=\left(W_{0} / W_{i}\right) \times 100(\%) \ldots \ldots \ldots \ldots \ldots \ldots
\end{array}
$$

〈2.2〉空間高謂波起磁力の影響 ボビンコイル モータでは一般汇每極每相溝数が 1 で $1 / 2$ の短節巻と なるために〈4・2〉節に示すように空間高調波起磁力の 影響が大きく，乙㣗を考虑する必要がある。图2(b) に示すように固定子歯幅汃 $\tau$ で，回転子導体の斜海の 角度（電気角）加 $\beta-\alpha$ とすると空妳の起磁力分布は 等価的汇台形とみるととができて四2(a)で表わすて 


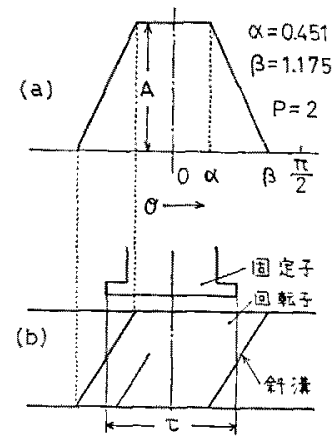

园 2 極の構造と起磁力波形

Fig. 2. Pole construction and $\mathrm{mmf}$ waveform.

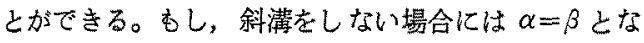
って方形となる。図2（a）○波形をフーリエ展開する

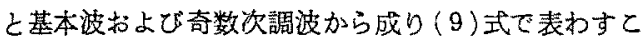
とができる。

$$
\begin{aligned}
b_{n} & =\frac{2}{\pi} \int_{0}^{\pi} f(x) \cos n \theta d \theta \\
& =\frac{4 A}{(\beta-\alpha) \pi n^{2}}\{\cos n \alpha-\cos n \beta\}
\end{aligned}
$$

固定子齿幅を磁束の広がりを考碳して，92度（管気 角）としで斜溝の大きさと各調波成分の大きさの関係 を(9)式で許算し区3に示す。同区の数佔はボビンコ イルモータに一般的に適用できると考えられる。主巻

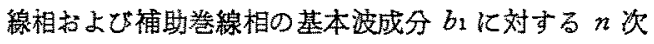
罚波成分の比 $k_{m n}\left(=k_{a n}\right)$ を四3に伊せて示した。主卷 線相に $\dot{I}_{m}$ ，補助巻線相（主巻線相换算値）に $\dot{I}_{\mathrm{g}}$ なる

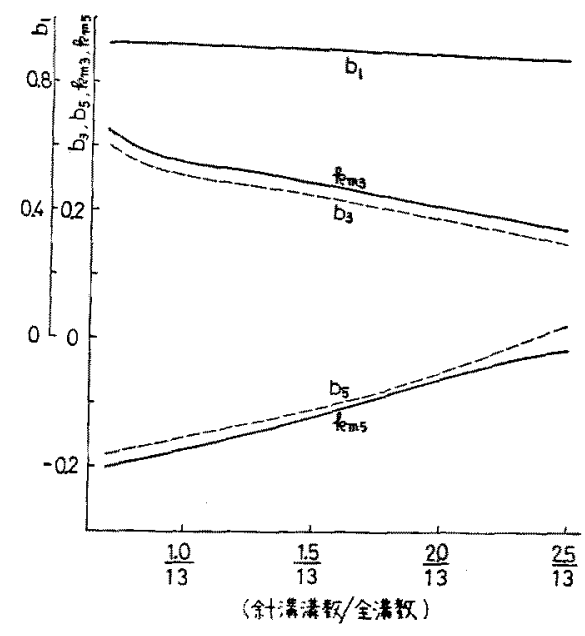

図 3 斜溝の $b_{1}, b_{3}, b_{5}, k_{m 3}, k_{m 5} \wedge$ 影響

Fig. 3. Effects of rotor skew on $b_{1}, b_{3}, b_{5}, k_{m 3}$ and $k_{m 5}$.
霞流を流したときの合成起磁力は

$$
\begin{aligned}
& \sqrt{2} W_{m} k_{m n} I_{m} \sin \left(\omega t+\varphi_{m}\right) \cos n \theta \\
& +\sqrt{2} W_{m} k_{a n} I_{a} \sin \left(\omega t+\varphi_{a}\right) \cos n(\theta-\pi / 2) \\
& \quad \equiv \sqrt{2} W_{m}\left\{I_{p n} \sin \left(\omega t-n \theta+\gamma_{2}\right)\right. \\
& \left.\quad+I_{n n} \sin \left(\omega t+n \theta+\gamma_{1}\right)\right\} \ldots \ldots \ldots \ldots(10)
\end{aligned}
$$

但し $\dot{I}_{m}, \dot{I}_{a}$ は

$$
\begin{aligned}
& \dot{I}_{m}=\dot{I}_{p}+\dot{I}_{n} \ldots \\
& \dot{I}_{a}=j\left(\dot{I}_{p}-\dot{I}_{n}\right)
\end{aligned}
$$

(10)式の $I_{p n}, I_{n n}$ は $n$ 次空間高調波電流で 極数は基 本波の $n$ 倍亡なり，1極あたりの巻数は基本波のそれ と等しいと考えるととができる。 $I_{p n}, I_{n n}$ は (13), (14) 式から求めるととができる。

$$
\begin{aligned}
I_{p n}= & (1 / 2) \sqrt{k_{m n}^{2} I_{m}^{2}+k_{a n}^{2} I_{a}^{2}} * \\
& *+2 k_{m n} k_{a n} I_{m} I_{a} \cos \left(\varphi_{m}-\varphi_{a}-n \pi / 2\right) \\
& \ldots \ldots \ldots \ldots \ldots \ldots \ldots \ldots \ldots \ldots \ldots \ldots \ldots \ldots \ldots \ldots \\
I_{n n}= & (1 / 2) \sqrt{k_{m n}^{2} I_{m}^{2}+k_{a n}^{2} I_{a}^{2}} * \\
& *+2 k_{m n} k_{a n} I_{m} I_{a} \cos \left(\varphi_{m}-\varphi_{a}+n \pi / 2\right)
\end{aligned}
$$

(10)式の $\gamma_{1}, \gamma_{2}$ は $I_{p n}, I_{n n}$ 成分の電源電王に対する位 相差よみるととができ

$$
\begin{aligned}
& \gamma_{1}=\tan ^{-1} \frac{k_{m n} I_{m} \sin \phi_{m}+k_{a n} I_{a} \sin \left(\phi_{a}-n \pi / 2\right)}{k_{m n} I_{m} \cos \phi_{m}+k_{a n} I_{a} \cos \left(\phi_{a}-n \pi / 2\right)} \\
& \gamma_{2}=\tan ^{-1} \frac{k_{m n} I_{m} \sin \phi_{m}+k_{a n} I_{a} \sin \left(\phi_{a}+n \pi / 2\right)}{k_{m n} I_{m} \cos \phi_{m}+k_{a n} I_{a} \cos \left(\phi_{a}+n \pi / 2\right)}
\end{aligned}
$$

この空間高調波電流 $I_{p n}, I_{n n}$ の求め方では，䶂単に するために $I_{p}, I_{n}$ を空間調波起磁力想視して (1)，

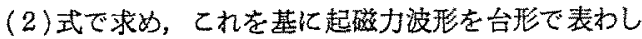
た。次にこの台形を(9)式でフーリ工展暨（図3)し， 基本波成分に対する空間高調波の比 $k_{m n}, k_{a n}$ を求め,

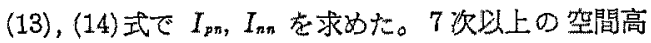

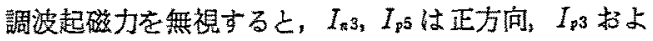
び $I_{n 5}$ は逆方向のトルクを発生し, 空間高調波起磁力 によるトルクは回転子提抗の電力から

$$
\begin{aligned}
T_{n}= & \frac{2}{4 \pi f /(p n)}\left\{I_{n 3}^{2} Z_{n r 3}+I_{p 5}{ }^{2} Z_{p r 5}\right. \\
& \left.-\left(I_{p 3}{ }^{2} Z_{p r 3}+I_{n 5}{ }^{2} Z_{n r 5}\right)\right\} \ldots \ldots . .
\end{aligned}
$$

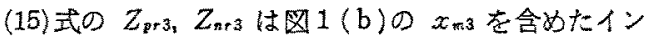
ピーダンス $\dot{Z}_{p 3}, \dot{Z}_{n 3}$ の车数部であり， $Z_{p r 5}, Z_{n+5}$ は (c)园の $\dot{Z}_{p 5}, \dot{Z}_{n 5}$ の奏数部である。(b), (c)図では 鉄損の等価抵抗は十分大きいものとして無視してい 乃。

$$
\dot{Z}_{p 3}=\frac{1}{\frac{1}{j x_{m 3}}+\frac{1}{r_{23} /(-3 s+4)+j x_{23}}}
$$




$$
\begin{aligned}
& \equiv Z_{n+3}+j Z_{p j 3} \\
\dot{Z}_{n 3}= & \frac{1}{\frac{1}{j x_{m 3}}+\frac{1}{r_{23} /(3 s-2)+j x_{23}}} \\
& \equiv Z_{n+3}+j Z_{n j 3} \\
\dot{Z}_{p 5}= & \frac{1}{j x_{m 5}}+\frac{1}{r_{25} /(5 s-4)+j x_{25}} \\
\equiv & Z_{p r 5}+j Z_{p j 5} \\
\dot{Z}_{n 5}= & \frac{1}{j x_{m 5}}+\frac{1}{r_{25} /(-5 s+6)+j x_{25}} \\
\equiv & Z_{n \tau 5}+j Z_{n j 5}
\end{aligned}
$$

\section{3. ブリッジの影響}

従来広く製作されているボビンコイルモー夕の固定 子の簙造な四4（a）に示ず。同図では1個のコイルだ けを图示したか，全体では4個のコイルで構成されて いる。との形の電動機の固定子はボビンに卷いたコイ ルを固定子㧘にはめ込み，てれをヨークに王入するす ので，コイル入れ作業を大幅に簢単にするこしができ る。図 4(a)の電動機では固定子の機械的強度を增す ために歯の先端がブリッジで磁気的に短絡されてい 方。

ブリッジで歯の先端を短絡することの運転特性に与 える影響を調べるためにブリッジのない譏種 $B$ 譏

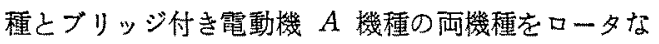
ごほかの条件を変えないで試作した。トルク，入力特 迭を测定して図 5 に示す。同図にはファン負荷の負荷 进線も併せて示してある加，負荷トルクは速度の自乗

(a)

A

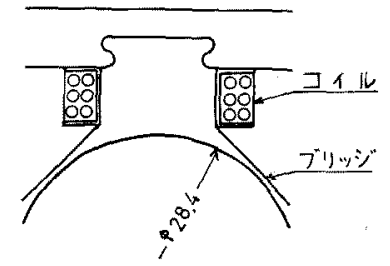

(b)

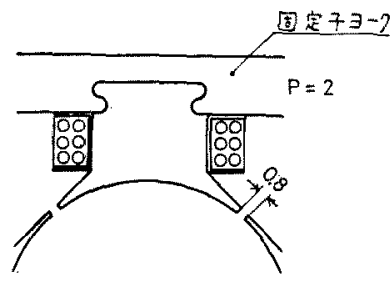

図 4 極の構造, プリッジ

Fig. 4. Construction of the pole piece, showing magnetic wedge.

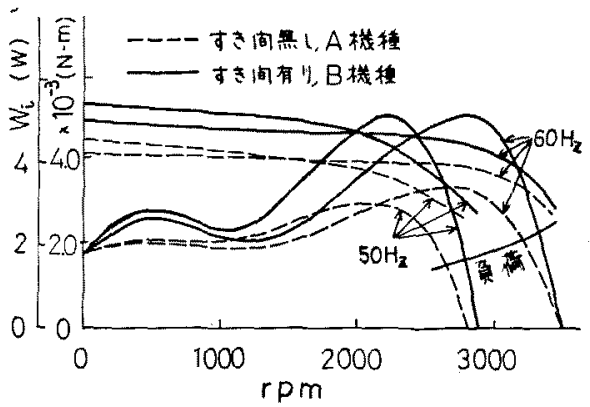

\begin{tabular}{|c|c|c|c|c|c|}
\hline \multirow{2}{*}{$\begin{array}{l}\text { ブリ } \\
\text { yシ }\end{array}$} & \multirow{2}{*}{$\left(\begin{array}{c}f \\
\left(H_{2}\right)\end{array}\right.$} & \multicolumn{2}{|c|}{ 最大奻率 } & \multicolumn{2}{|c|}{ ファン䚁荷 } \\
\hline & & $Y_{m}(\%)$ & rpm & $Y(\%)$ & $\mathrm{rpm}$ \\
\hline \multirow{2}{*}{$\begin{array}{c}\text { 有 } \\
\text { A }\end{array}$} & 50 & 19.0 & 2300 & 14.6 & 2630 \\
\hline & 60 & 25.6 & 2900 & 220 & 3170 \\
\hline \multirow{2}{*}{ 無 } & 50 & 29.3 & 2500 & 16.1 & 2780 \\
\hline & 60 & 35.5 & 3000 & 25.3 & 3310 \\
\hline
\end{tabular}

図 5 ブリッジの特性への影響

Fig. 5. Effects of the magnetic wedge on characteristics.

\section{表 1 ブリッジの効率への影響}

Table 1. Effects of the magnetic wedge on efficiency.

に比例するとみることができる。図5のトルクの湘定 はヒステリシス形トルク計を使用しており，トルクの 谷の部分も測定が可能になっている。四 5 から最大効 率 $Y_{m}$ 抽よびファン負荷を付けたときの效率を求的表 1に示す。ブリッジをなくして屚れ磁束を減らすとと によって $Y_{m}$ は $50 \mathrm{~Hz}$ で $10,3 \%, 60 \mathrm{~Hz}$ で $9.9 \%$ 高 くなっている。また, ファン真荷を付けた実際の使用 速度で比较しても $50 \mathrm{~Hz}$ で $1.5 \%, 60 \mathrm{~Hz}$ で $3.3 \%$ 高

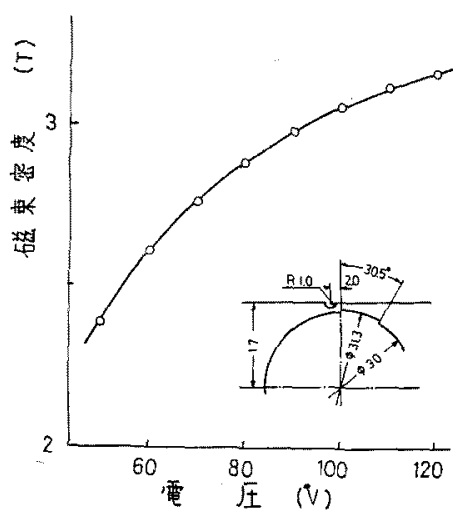

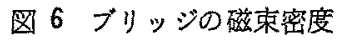

Fig. 6. Magnetic flux density in the magnetic wedge. 
くなるととがわかる。これはブリッジをなくすと入力 の增加以上にトルクが大幅に增すためで，ブリッジの 漏机磁束に起因しているとみられる。

㐘の先端が短絡（因6）された機種についてブリ

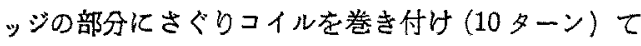
漏れ磁束を測定し，最す㹟い所の磁束密度を求》图 6 亿示す。同図から，使用電生の籍围で磁束密度住 2.8 〜3.2T となるととがわかる。この結果から図50A 桠種を基漼にブリッジの漏れ磁束の率を求めると，磁 束密度 $3 \mathrm{~T}$, ブリッジ厚さ $0.5 \mathrm{~mm}$ ，すべり 0.2 とし て，24\%となった。ブリッジの嬮さはてれ以上薄く することは困難とみられるので，ボビンコイルモータ (特に小形の)の漏れ磁束の率住かなり高くなるとと がかかる。

\section{4. 定数の誤差}

〈4.1〉測定定数による特性計算 图 5 および表 1からブリッジをなくして歯の先端を開放した方が良 好な特性が得られることがわかっだ。そてで，量産を 考慮して寸法を多少修正してブリッジのない機種Cを 再度試作した。このC機を両相の起磁力の大きさが等 しく，位相差が $\pi / 2$ となるような電什で励磁したと きの拘束時朽よび無負荷時の電流，入力，ならびに無 負荷回轻数，一次巻線抵抗 $r_{1} の 6$ 項目を测定し表 2

表 2

Table 2.

（a）定数决定のための测定テータ (a) Measured data for parameter determination.

\begin{tabular}{|c|c|c|}
\hline 測定項目 & 测定俌 & 測定電厓 \\
\hline 器貢何回転数 & $2920 \mathrm{rpm}$ & $100 \mathrm{~V}$ \\
\hline “電流 & $33.2 \mathrm{~mA}$ & $\Rightarrow$ \\
\hline$=\lambda \hbar$ & $1.23 W$ & " \\
\hline 拘束時流 & $48.0 \mathrm{~mA}$ & $80 \mathrm{~V}$ \\
\hline$\lambda カ$ & $2.50 \mathrm{~W}$ & " \\
\hline & $r_{1}=546$ & $50 \mathrm{~Hz}_{2}$ \\
\hline
\end{tabular}

(b) 測定定数之設計定数

(b) Measured parameters and design parameters.

\begin{tabular}{r|r|r}
\hline 定教 & 測定定数 & 設計定数 \\
\hline$r_{1}$ & 546.0 & $(546.0)$ \\
\hline$x_{1}$ & 646.8 & 700.0 \\
\hline$x_{2}$ & 646.8 & 869.6 \\
\hline$x_{m}$ & 2304.5 & 2147.0 \\
\hline$r_{2}$ & 960.0 & 679.3 \\
\hline$r_{i}$ & 11449.5 & $(11449.5)$ \\
\hline \multicolumn{4}{c}{ C 機種 }
\end{tabular}

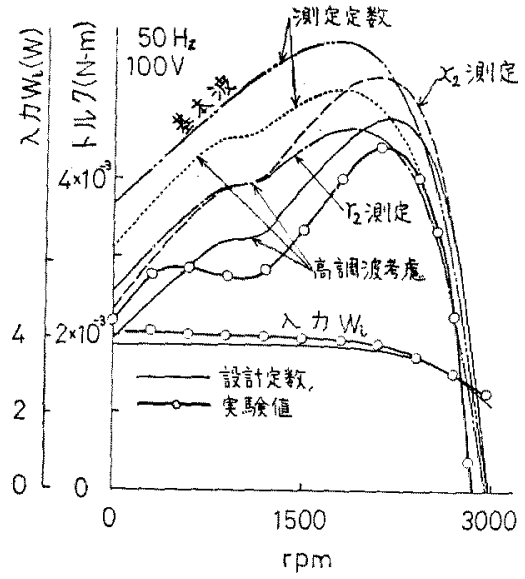

図 7 計算結果亡奏験結果の比較，C機種

Fig. 7. Comparison of test and computed results, machine $C$.

表 3 三次および五次の空間高調波の定数 Table 3. Parameters for third and 5-th space harmonics.

\begin{tabular}{|c|c|c|c|}
\hline$f_{m s}$ & 0.246 & $t_{m s}$ & -0.120 \\
\hline$x_{\mathrm{m} 3}$ & 2392.8 & $x_{n 5}$ & 2392.8 \\
\hline$x_{23}$ & 5364,4 & $x_{25}$ & 10139.9 \\
\hline$\Gamma_{23}$ & 2127.3 & $T_{25}$ & 50689 \\
\hline
\end{tabular}

（a）に示す。但し，拘束時の電圧は過熱を避けるため に 80\%に下げて測定した。

ボビンコイルモータの正相分等価回路を図 1 (a)で 表わ当ものとして定数を求め表 2 (b)化示す。同表の 定数はこの值を使って逆汇最初に与えた電流执よび入 力の值を計算すると完全に一致するように繰返し，電 流，入力の方を修正して精度を向上（誤差 $0.1 \%$ 以 下)させたものである(6)。コンデンサモータでは始動 トルクを大をするために $r_{2}$ 比較的大きくとるの で，一般江使用されている定数决定法を適用すると $r_{2}, x_{1}\left(\equiv x_{2}\right)$ 化大きな铞差を生ずる問題がある。

表 2 (b) の測定定数を使って正相分電流 $\dot{I}_{p}$ および 逆相分電流 $\dot{I}_{n}$ を(1)，(2) 式を使って求め，(5)式で卜 ルクを計算し，実驗結果と比較してそれぞれ因7の2 点さ線上太い実線で示す。この計算植は空間高調波起 磁力在視したときの特性であるが，実験值と比べて かなり大きくなっている。てのように大きな誤差を生 ずるのはボビンコイルモータ特有の現象とみられる。 $\langle 4 \cdot 2\rangle \sim\langle 4 \cdot 3\rangle$ 節ではこの原因を究明する。

〈4.2〉空間高謂波起磁力を若虑した場合 起磁 力分布志図2の台形で表わし，図7に示したC機種の 


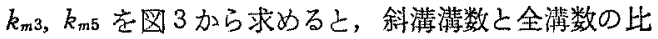
が 1.5/13であることから $k_{m 3}=0.246, k_{m 5}=-0.120$ となる。なお，乙の場合の $\alpha, \beta$ (図2）は $\alpha=0.451$ $\mathrm{rad}, \beta=1.175$ である。空間高調波電流 $I_{p n}, I_{n n}$ はそ れぞれ(13)，(14)式て求められる。空間高調波分の定 数を各極の巻数が基本波のそれ之等しく，極数が基本 波の $n$ 倍之考元て寸法，材質（設計定数）加ら求めて 表了に示す。

表 2 の基本波に対する測定定数求よび表 3 の空間高 調波の定数を使って(1)〜 (5)，(11)〜(15)式拉よび 四3(あるいは（9)式）老使ってトル夕を計算し，図 7 の点線で示す。空間高調波起磁力老考慮することに よって哭駼值代近付く傾问はみられるが，まだ大きな 誤差が認められる。

$\langle 4 \cdot 3\rangle$ 測定定数之設計定数の比輍 测定定数を 使ってトルクを計算すると，空間高調波起磁力を考慮 してすかなり大きな誤差が生ずるととがわかった。 の原因として測定定数の誤差が考えられるので, 寸法 市よび材質加ら定数計算（設計定数）し，测定定数 ととむ江表 $2(\mathrm{~b})$ 亿示す。同表で両者を比較すると $x_{2}$ 极上び $r_{2}$ 亿扔いて大きな差がみられる。

設計定数の $x_{2}$ が $x_{1}$ に比へて大きくなるのは, 固 定子の洴数が 4 であるのに対して回転子は 13 湿であ るために二次側の千鳥漏れリアクタンス $x x_{h}^{(7)}$ が大き くなるのが原因とるら机る。これ结，二次電流㮩よっ て発生した磁束が固定子の歯幅か㳎いために迷の中を 通り，一次導体とさ交せずに漏れ磁束になるためで ある。C機種では一次側の千鳥漏れリアクタンスは $262.8 \Omega$ と $x_{1}$ 全体の $37 \%$ であるのに対して，二次の

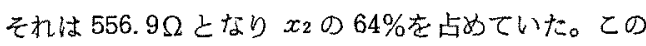
ようにブリッジがないボビンコイルをータでは一般に $x_{2}>x_{1}$ となると考えられる。

測定では $x_{1}$ と $x_{2}$ の分離は困蜼であるが，表 $2(b)$ で $x_{1}+x_{2}$ について比較すると測定值の方加設計定数 に比べて小さくなっている。この原因としては, 空間 高調波の入力などによって二次抵抗 $r_{2}$ が大きくなる ことの影響が考えられる。 $r_{2}$ の測定値が大きくなる 原因としては空間高調波の入力が基本波の入力として 加わってしまうとと(測定定数は空間高調波を無視し て求めているのほ加，次のて之加考方られる。 $x_{2}$ が $x_{1}$ に比べて大きいと， $x_{1}=x_{2}$ として定数を決定 しているので $x_{1}$ (測定德) が大きくなり，そのぶんだ け $x_{m}$ が小さくなって，拘束時の二次電流を小さく見 皘ってしまうために r が大きくなると考えられる。

設計定数を使用し，空間高調波起磁力を考慮して (1)〜(5)，(11)〜(15) 式でトルタを計算して図7の
細い実線で示す。計算值は実験值とほぼ一致している とみられる。また， $x_{2}$ あるいは $r_{2}$ 亿測定值を使用し た場合の曲線も侀せて図示した。 $x_{2}$ 亿測定定数を使 うとトルクが全体的に大、きくなり，また，r注測定 定数を使うと最大卜ルクのすべりが低速僛化鸟る傾 向がタられる。入力 $W$ を(6)式で計算し, 実験值と 比較して図7亿併せて示した。廦者は良く一票してい るとみるこよができる。

以上の比較加ら図 4(b)のような極の非状をしたボ ビンコイルモータでは空間高調诐起磁力の影響を考慮 する必要があること，空間高調波起磁力によって同期 速度の約 $1 / 3$ のところで速度住するトルクの增加率 加低下する現象があるとと， $x_{2}$ 扔よび 2 の测定定数 に大きな哭差が生ずることなどがわかった。

〈4.4〉効率むよび二次抵抗の配分 図 7 に示し たボビンコイルモータC機種の最大効率 $Y_{m}$ は $28.8 \%$ であるが，普通の形の市販されているコンデンサモー タの $Y_{m}$ (測定值)とを比較して図8に示す。同図か らボビンコイルモータの $Y_{m}$ は小形のわりにはかなり 高いとみることができる。

くま取りモータに拈いて r を一定に保ちながらパ 一の断面皘を大きくとるととにより，空間高調波によ る銅損を減らせることが，定性的ではするが報告され ている(8)。民てで, 空間高調波起磁力が特に大きいボ ビンコイルニータについて二次抵抗の配分の影響につ いて検討する。

図7のC 機種について基本波の二次抵抗疮 $r_{2}=$ $679.3 \Omega$ に一定に保ち，バ一の断面樍を 0.5 倍，1.0 (基準) 倍， 2.0 倍としたとときの空間高調波起磁力に よるトルク $T_{3}+T_{5}$ および $T_{5}$ を(11)〜 (15) 式で計算 し図 9 に示す。バーの断面積を $0.5,1.0,2.0$ 倍とし

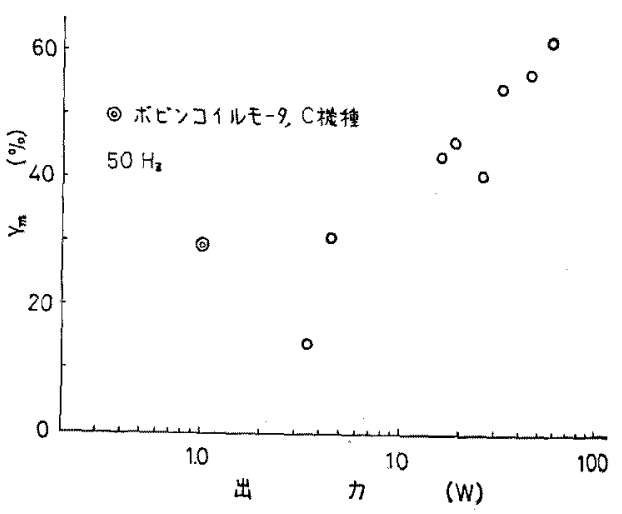

図 8 コンデンサモータの最大効率

Fig. 8. Maximum efficiency of capacitor motors: 


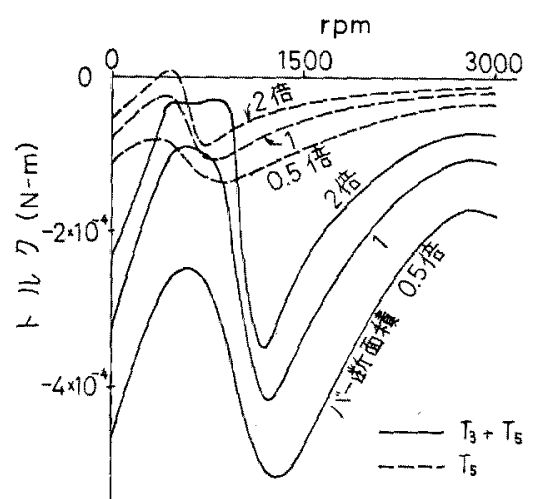

図 9 ロータバー断面皘の空間高䶂波トルク

$T_{3}, T_{5}$ への影響。口-名抵抗 $r_{2}$ は一定

Fig. 9. Effects of cross section area of rotor bar on space harmonic torque $T_{3}$ and $T_{5}$. Rotor resistance $r_{2}$ is held constant.

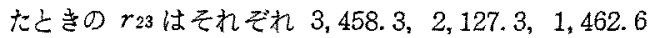

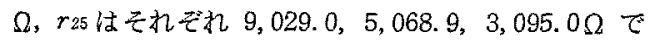
あった。空間高調波起磁力に上るトルクは同期速度の $1 / 3$ より少し高速のところで逆方向トルクの極大值を とること，第 3 調波によるトルクが第 5 に比でて大き いとと，バーの断面皘を広くとった方が $r_{23}$ ，r25 注小 さくなる傾向があり，空間高調波起磁力による影響加 少なく，良好なトルク特性が得られ，効率が高くなる ことなどがわかった。

\section{5. 主巻線と補助巻線を直列接続する方式}

コンデンサモータの巻線は多くの場合図 10（a）の ように両相がそれぞれ電源に並列に接続されるが，出 力が小さい機種にての方式探用すると巻数が多くな り，線程が細くなって断線事故を起す危険が出てく る。そこで, 補助巻線と並列にコンデンサを接続し，

これと直列汇主巻線を接続する図10(b)の方式が採 用されることがある。図70C機種は四10(a)の結 線方式で，線径が $0.12 \mathrm{~mm}$ であるが，てれがほほ限 界で，更似小形上する場合仕图10(b)の結線亡した 方が良いと考えられる。本章ではこの結線方式のモー 夕の解析法仪ついて检討する。

図 10（b）の主巻線亡補助巻線の直列回路について 電壬の関係を求めると(16)式少得られる。また, 補助 卷線亡コンデンサの並列回路の電圧について(17)式が 成立する。

$$
\begin{gathered}
\dot{I}_{m}\left(r_{1}+j x_{1}\right)+\dot{I}_{p} \dot{Z}_{p}+\dot{I}_{n} \dot{Z}_{n}+\dot{I}_{a^{\prime}}\left(a^{2} k_{1} r_{1}\right. \\
\left.\quad+j a^{2} x_{1}\right)-j a \dot{I}_{p} \dot{Z}_{p}+j a \dot{I}_{n} \dot{Z}_{n}=V_{1}
\end{gathered}
$$
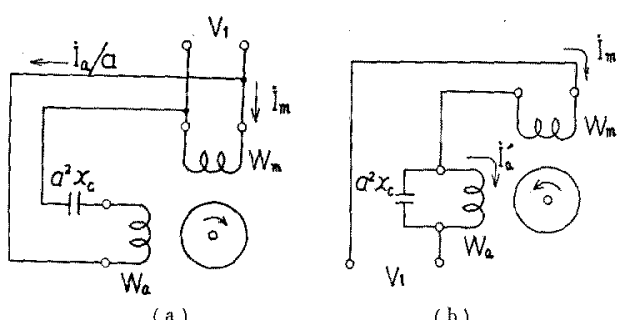

(b)

図10 コンデンサモータの維線

Fig. 10. Winding connections of capacitor motor.

$$
\begin{aligned}
& \dot{I}_{a}{ }^{\prime}\left(a^{2} k_{1} r_{1}+j a^{2} x_{1}\right)-j a \dot{I}_{p} \dot{Z}_{p}+j a \dot{I}_{n} \dot{Z}_{n} \\
& \quad+j a^{2} x_{c}\left(\dot{I}_{m}-\dot{I}_{a} a^{\prime}\right)=0 \ldots \ldots \ldots \ldots \ldots \ldots(17)
\end{aligned}
$$

但し， $k_{1}$ は雨相の銅量比 (主/補)， $\dot{I}_{a}^{\prime}$ は実際の補助 巻線電流 (末换算値)である。電流については主巻線 相で(18)式，補助巻線相で(19)式が成立する。

$$
\begin{aligned}
& \dot{I}_{m}=\dot{I}_{p}+\dot{I}_{n} \ldots \ldots \ldots \ldots . . . \\
& \dot{I}_{a^{\prime}}=\left(-j \dot{I}_{p}+j \dot{I}_{n}\right) / a .
\end{aligned}
$$

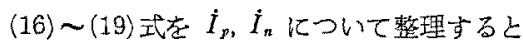

$$
\begin{aligned}
& \left\{r_{1}+j x_{1}+\dot{Z}_{P}-j a k_{1} r_{1}+a x_{1}-j a \dot{Z}_{p}\right\} \dot{I}_{p} \\
& +\left\{r_{1}+j x_{1}+\dot{Z}_{n}+j a k_{1} r_{1}-a x_{1}+j a \dot{Z}_{n}\right\} \dot{I}_{n} \\
& \equiv D_{1} \dot{I}_{p}+D_{2} \dot{I}_{n}=V_{1} \ldots \ldots \ldots \ldots \ldots \ldots \ldots(20) \\
& \left\{-j a k_{1} r_{1}+a x_{1}-j a \dot{Z}_{p}+j a^{2} x_{c}-a x_{c}\right\} \dot{I}_{p} \\
& +\left\{j a k_{1} r_{1}-a x_{1}+j a \dot{Z}_{n}+j a^{2} x_{c}+a x_{c}\right\} \dot{I}_{n} \\
& \equiv D_{3} \dot{I}_{p}+D_{4} \dot{I}_{n}=0 \ldots \ldots \ldots \ldots \ldots \ldots \ldots \ldots(21)
\end{aligned}
$$

(20), (21)式吕ら $\dot{I}_{p}, \dot{I}_{n}$ 㕲

$$
\begin{aligned}
& \dot{I}_{p}=\frac{D_{4}}{D_{1} D_{4}-D_{2} D_{3}} V_{1} \\
& \dot{I}_{n}=\frac{-D_{3}}{D_{1} D_{4}-D_{2} D_{3}} V_{1}
\end{aligned}
$$

平衡運転条件怡 $D_{3}=0$ 加ら求まり，実数部加零の 条件加ら $x_{0}$ 名，虚数部が零の条件から $a$ が求まる。

$$
\begin{aligned}
& x_{c}=x_{1}+Z_{p j} \\
& a=\frac{k_{1} r_{1}+Z_{p r}}{x_{1}+Z_{p j}}
\end{aligned}
$$

$Z_{p r}, Z_{p}$ は は(3)式で求まる。普通の結線方式图 10(a) の平衡運転条件は二つ加ら成り，容量は補助卷線相の 並列共振の容量, 巻数比はりアクタンス成分上抵抗成 分の比であった ${ }^{(9)}$ 。乙れに対し，ての形式の結線図 10 (b) の平衡運転条件は (24)，(25)式加ら容量值列共 振コンデンサの容量となり，巻数比は逆低抗成分之 リアクタンス成分の比之なることがわかる。トルクは (5)式，入力は $\dot{I}_{m}$ の $V_{1}$ に対する位相を $\varphi_{m}$ とする と(26)式で求まり，出力标 $(7)$ 式，勃率仙 (26)，(8) 式，電流は(18)式で求めることができる。 


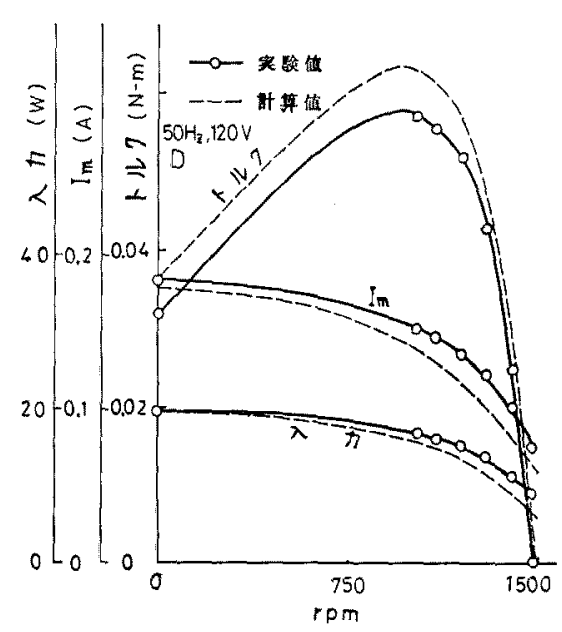

図 11 計算結果と実験結果の比較, コンデンサ 之補助巻線並列接続

Fig. 11. Comparison of test and computed results. Capacitor is connected in parallel to auxiliary winding.

$$
W_{i}=V_{1} I_{m} \cos \varphi_{m}
$$

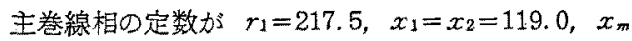
$=1,095.5, r_{2}=280.1 \Omega$ て, 極数 $p=4, x_{0}=814.4$ $\Omega, a=0.564$ の D機種について図 $10(\mathrm{~b})$ の結線の場 合の特性を (20)〜 (23), (5), (26) 式で計算し，実験結 果と之も图11亿示す。同図では特性をより正確に 此较するために空間高謂波の少ない每極每相の港数が 2 の普通の形のコンデンサモータ（ボビンコイルモー タでないにについて比較したすのでそそのために空間 高調波起磁力の影響はみられない。図11で計算結果 と実験結果は良く一致しており，乙の解析法注妥当な むのとみることができる。

\section{6. ま と}

冷蔵庫のファンモータとして, 多くの場合, 出力 1 $\mathrm{W}$ ，入力 $8 \mathrm{~W}$ 程度のくま取り電動機が使用されてい たか，乙れの省力化を图ったととろ，入力 $6.5 \mathrm{~W}$ ま で哇小さくなった。しかし，てれが限界で市った。を こで，構造が簡単なボビンコイルモータで更に入力の 低減を図り，C機種では入力 $3.5 \mathrm{~W}$, 最大效率 28.8 \%まで改善できた。この過程において，ボビンコイル モータでは三つの固有の問題があるととがわかった。

第1点はブリッジの影響を明らか汇することで，ブ リッジをなくして歯の先端を開放した方が効率は高く なるとと，開放するるえ力が增加するが，それ以上に トルクが堌加することなどがかかった。第 2 点は測定
定数の誤差が大きいことで，特に二次漏れリアクタン

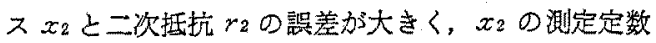
は小さく，r2のそれは大きくなるととがわかった。ま た，これらの䛇差の発生原因を示し，ての誤差がトル ク特性に与える影響を求めた。第 3 点は同期速度の約 1/3の之ころで速度に詨するトルクの增加率が低下す る現象が古り，之の原因は空間高調波起磁力に方るこ 之を示した。ボビンコイルモータでは約 $1 / 2$ の短節巻 となるため空間高調波起磁力の影響は一般的に大き いと考元られる。また，バーとエンドリングの抵抗の 配分が空間高調波起磁力によるトルクに与元る影響を 明らかにした。バーの断面皘を大きくして三次調波の 二次抵抗 $r_{23}$ 占上び五次調波の二次抵抗 $r_{25}$ 索小さく （ｒ２は一定）すると逆方向のトルク放さくなり，効 率を高くできることを示した。

本文で示したボビンコイルモータより小形にするに は，線径が細くなり断線の問題が出てくる。との対策 としてコンデンサを補助巻線と並列に接続し，てれを 主巻線值列に接続することがあるが，ての結線のも 一タの特性の解析法, 平衡運転条件の式などが得られ た。平衡運䎐条件は巻数比 $a$ とコンデンサのリアクタ ンス $x_{c}$ 加ら成るが，aは普通の結線と逆化入力イン ピーダンスの抵抗成尔とリアクタンス成分の比になる こと， $x_{c}$ の容量は普通の結線では補助巻楾相の並列 共振コンデンサとなるのに対し，乙の結線では直列共 振コンデンサの容量になるととなどがわかった。

終りにあたり，御指遒いただいた本学の須藤二全教 授驸謝意を表します。（昭和 58 年 11 月 10 日受付)

\section{文献}

(1) W.J. Morrill: "The Revolving Field Theory of the Capacitor Motor" Trans. AIEE, 48, 614 (1929-4)

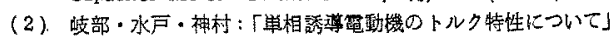
電学誌 82, 190 (昭 37-2)

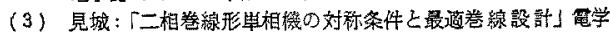
誌 89,957 (昭 44-5)

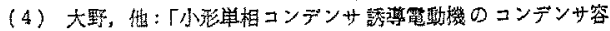

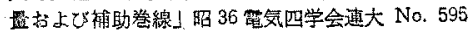

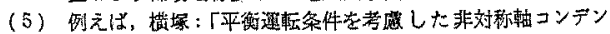
サモー夕」電学諭B 98, 169 ( (昭 53-2)

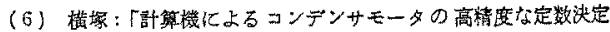

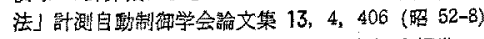

(7) 上曰: 電気㙨㳦設部 p. 144 (圆 24-11) 文独堂

(8) S. S.L. Chang: "Equivalent Circuits and Their Application in Designing Shaded Pole Motors" AIEE Trans. 70, 690 (1951)

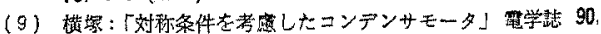
181 (昭 45-10)

(10)棤塚，他:「ボビンコイル形コンデンサモータの閒発」明 58 電気学会全大 No. 747 